\title{
Meningkatkan Produktivitas Kerja Karyawan Melalui Motivasi PT. Orson Indonesia (Bagian Pabrik)
}

\author{
Anisa Nuraeni Mardini ${ }^{1}$, Yacobo P. Sijabat ${ }^{2}$ \\ ${ }^{12}$ Universitas Tidar, Indonesia \\ ${ }^{*}$ Korespondensi: anisanuraeni7854@gmail.com
}

\begin{abstract}
Abstrak: Dalam mempertahankan eksistensi dan kinerja perusahaan, komponen sumber daya manusia (SDM) memegang peran penting terhadap performa perusahaan. Tingginya motivasi SDM akan berbanding lurus dengan produktivitas yang berhubungan langsung dengan performa perusahaan. Tujuan dari penelitian ini adalah untuk melakukan pengamatan dan penelitian terhadap faktor-faktor yang berhubungan dengan meningkatkan produktivitas karyawan dan mengevaluasi sejauh mana motivasi telah dilakukan sebagai bahan referensi yang dapat digunakan oleh perusahaan dalam menentukan kebijakan pengembangan sumber daya manusianya. Metode yang digunakan dalam penelitian ini adalah metode penelitian kualitatif-deskriptif dalam bentuk wawancaran dengan manajer pabrik dengan pendekatan studi literatur yang bersumber dari 22 artikel ilmiah. Hasil penelitian menunjukkan bahwa meningkatkan produktivitas kerja karyawan melalui motivasi dapat dilakukan perusahaan dengan memberikan pendidikan dan pelatihan, meeting koordinasi, briefing rutin, fasilitas yang memadai, reward dan punishment. Meningkatkan produktivitas kerja karyawan menjadi prioritas perusahaan dalam membangun motivasi kerja yang kuat. Motivasi kerja yang kuat dapat memberikan keuntungan dan keunggulan kompetitif bagi perusahaan.
\end{abstract}

Kata-kata kunci: Meningkatkan, Produktivitas Karyawan, Motivasi.

Abstract: In maintaining the existence and performance of the company, the component of human resources (HR) plays an important role in the company's performance. The high motivation of HR will be directly proportional to productivity which is directly related to company performance. The purpose of this study is to conduct observations and research on factors related to increasing employee productivity and evaluate the extent to which motivation has been used as a reference material that can be used by companies in determining their human resource development policies. The method used in this study is a qualitative-descriptive research method in the form of interviews with factory managers with a literature study approach sourced from 22 scientific articles. The results show that increasing employee productivity through motivation can be done by the company by providing education and training, coordination meetings, routine briefings, adequate facilities, rewards and punishments. Increasing 
employee productivity is the company's priority in building strong work motivation. Strong work motivation can provide competitive advantages and advantages for the company.

Keywords: Increase, Employee Productivity, Motivation.

\section{Pendahuluan}

Dalam perkembangan saat ini sumber daya manusia bukan hanya sekadar aset utama, tetapi juga aset bernilai yang dapat dikembangkan dan digunakan sebagai investasi dalam suatu organisasi (Bukit et al., 2017). Karyawan suatu perusahaan berperanan penting dalam mencapai tujuan organisasi yang telah ditetapkan (Husaini, 2017). Potensi karyawan dapat terus berkembang jika perusahaan menciptakan lingkungan kerja yang aman dan nyaman serta memperhatikan kebijakan perusahaan. Apabila kinerja karyawan rendah maka akan menghambat keberhasilan dalam mencapai tujuan perusahaan. Hal ini akan berdampak buruk terhadap keberhasilan perusahaan, sehingga menghambat operasional perusahaan.

Beberapa hal yang harus diperhatikan oleh manajemen yang berbasis kepada sumber daya manusia adalah tingkat keterampilan dan kemampuan yang dimiliki oleh karyawan, serta kemampuan yang dimiliki oleh perusahaan dalam melakukan pemberdayaan kepada sumber daya manusianya untuk dapat menggapai tujuan yang dimiliki oleh perusahaan, selain itu juga agar dapat menciptakan kinerja dari karyawan menjadi tinggi dan bisa menghasilkan kinerja dari organisasi menjadi tinggi pula.

Selain itu, juga melalui budaya organisasi yang berperan penting dalam variabilitas sistem pengukuran kinerja seperti kepuasan kerja anggota organisasinya, etos kerja di dalam organisasi dan motivasi kerja karyawan. Menurut (Alamzah \& Simanjutak, 2013), manajemen sumber daya manusia perlu mengetahui tingkat keterampilan dan kemampuan karyawan, sehingga dengan begitu, perusahaan dapat menentukan arah strategi sumber daya manusia yang tepat dapat diterapkan oleh organisasi agar dapat berjalan secara efektif dan efisien. 
Peningkatan motivasi SDM atau karyawan perusahaan akan menciptakan keunggulan perusahaan yang juga akan berdampak dalam meningkatkan citra perusahaan pada produk barang dan jasa yang ditawarkan, perusahaan wajib membangun hubungan yang positif dengan karyawan. Untuk mendukung visi dan misi perusahaan, kinerja karyawan yang tinggi tentu dapat dicapai jika motivasi karyawan juga tinggi.(Hermawan \& Rahadi, 2021). Memberikan motivasi pada karyawan mempunyai tujuan dan memiliki dampak pada perilaku dari individu di tempat kerja. Beberapa dampak dan tujuan dari motivasi kerja menurut Hasibuan pada (Purbaningtyas \& Muchollasho, 2020) yaitu keberhasilan perusahaan dapat tercapai melalui peningkatan kinerja karyawan, produktivitas karyawan, dan kepuasan kerja karyawan.

Hasil penelitian oleh beberapa peneliti (Wicaksono, 2011), (Muslikhah, 2011), (Prihantoro, 2012), (Rahmawati, 2013), (Mudayana \& Suryoko, 2016), (Hoornweg et al., 2016), (Moulana et al., 2017), (Budianto et al., 2017), (Safitri, 2017), (NST \& Lesmana, 2018), (Purnomo \& Wahdiniwaty, 2018), (Aboelmaged, 2018), (Laksmiari, 2019), (Oktiani et al., 2019), (Sutrisno \& Sunarsi, 2019), (Falah \& Ayuningtias, 2020), (Marlapa \& Mulyana, 2020), (Parmana et al., 2020), (Suryantika \& Wibawa, 2020), (Imas Masriah, 2020), dan (Amalia et al., 2021), menyatakan bahwa motivasi kerja karyawan berhubungan secara signifikan positif terhadap produktivitas karyawan. Berbeda dengan pendapat yang dinyatakan oleh (Kristine, 2017), bahwa kepuasan kerja memiliki pengaruh signifikan negatif pada kinerja karena dipengaruhi oleh faktor individu yaitu harga diri. Karyawan dengan harga diri yang tinggi, beranggapan bahwa dirinya berharga dan yakin akan kemampuannya, hal tersebut menyebabkan tugas utamanya menjadi beban dan kepuasan yang diperoleh dapat menurunkan kinerjanya.

PT. Orson Indonesia merupakan sebuah perusahaan internasional yang berfokus pada mengembangkan usaha sabun mie, sabun toilet, sabun serbaguna dan cucian dan aneka ragam produk untuk kepentingan konsumen di seluruh dunia, serta memiliki cukup banyak karyawan terutama pada bagian 
pabrik, maka perusahaan menjalankan kegiatannya mengandalkan produktivitas karyawan agar tetap terus maju dan berkembang. Penelitian ini bertujuan untuk mengidentifikasi upaya meningkatkan produktivitas kerja karyawan melalui motivasi yang diberikan dan tingkat motivasi yang digunakan, dengan harapan memperoleh sumber daya yang potensial dan berkualitas yaitu mampu menyelesaikan tugas dengan baik dan handal dalam segala bidang, memperlancar kerja produksi dan mengurangi kendala yang dialami perusahaan. Hasil penelitian ini diharapkan dapat memberikan informasi dan rujukan untuk meningkatkan motivasi kerja karyawan.

\section{Metode Penelitian}

Jenis data dalam penelitian ini menggunakan studi literatur berupa 22 artikel ilmiah yang diperoleh dari penelitian sebelumnya yang sesuai dengan topik yang dikaji dalam penelitian dalam rentang waktu 10 tahun dan wawancara. Bogdan dan Taylor (dalam Moleong, 2017:4) mendefinisikan metodologi kualitatif sebagai prosedur penelitian yang menghasilkan data deskriptif berupa kata-kata tertulis atau lisan dari orang-orang dan perilaku yang dapat diamati. Metode yang digunakan dalam penelitian ini adalah metode deskriptif dengan pendekatan kualitatif. Penelitian kualitatif adalah penelitian yang bermaksud untuk memahami fenomena tentang apa yang dialami oleh subjek penelitian, misalnya perilaku, persepsi, motivasi, tindakan, dan lain-lain secara holistik, dan dengan cara deskripsi dalam bentuk kata-kata dan bahasa, pada suatu konteks khusus yang alamiah dan dengan memanfaatkan berbagai metode alamiah (Moleong, 2017:6).

Dalam penelitian pengambilan sampel menggunakan purposive sampling. Informan dalam penelitian ini adalah manajer pabrik. Untuk mendapatkan data dilakukan dengan wawancara atau tanya jawab dengan pihak yang bersangkutan dalam hal informan guna mendapatkan data dan keterangan yang menunjang penelitian. Tujuan penelitian ini adalah mendeskripsikan produktivitas kerja karyawan melalui motivasi PT. Orson Indonesia (divisi pabrik). Oleh karena itu, penelitian ini merupakan penelitian kualitatif dengan 
analisis secara deskriptif. Secara umum, prosedur yang ditempuh dalam penelitian ini adalah sebagai berikut: melakukan studi pustaka, mengumpulkan data, menyeleksi data, mengelompokkan data, menganalisis data, menyajikan hasil analisis data, dan melaporkan hasil penelitian. Dan tahap pelaksanaan penelitian ini adalah sebagai berikut: penentuan informan, wawancara, pengumpulan data hasil wawancara, dan keabsahan data.

\section{Hasil dan Pembahasan}

\section{Distribusi Artikel}

Penelitian ini merupakan studi literatur dengan menggunakan 22 jurnal, 7 di antaranya merupakan jurnal internasional dan 15 jurnal nasional. Hasil data yang diperoleh dari mesin pencarian yaitu sebesar 54,5\% dari Google Scholar, 27,2\% Research Gate, 9\% Emerald, dan 9\% berasal dari Elsevier. Penelitian yang membahas variabel produktivitas kerja karyawan sebanyak 14 jurnal, sedangkan motivasi 21 jurnal. Analisis data yang digunakan dalam penelitian, 90\% menggunakan software SPSS, 4,5\% dengan PLS (Partial Least Square) dan 4,5\% menggunakan SEM (Structural Equation Model). Rata-rata sampel yang digunakan dalam penelitian sebanyak 84 responden di mana objek penelitian adalah karyawan di berbagai sektor industri.

\subsection{Hasil Penelitian}

Berdasarkan wawancara yang peneliti lakukan dengan Bapak Heru Saprullah sebagai manajer pabrik pada PT. Orson Indonesia mengenai tingkat produksi perusahaan dengan target yang diukur menggunakan OEE (Overall Equipment Effectiveness) sebagai dasar dalam usaha perbaikan dan peningkatan efektivitas dan produktivitas dari sistem manufaktur perusahaan di PT. Orson Indonesia yang mana untuk mengukur efektivitas produksi dalam menjalankan pabrik dengan persentase 75\% sudah tercapai dan tingkat limbah 0,8\%. Cakupan OEE (Overall Equipment Effectiveness) produksi meliputi: availability machine, production machine, and rejection product. 


\subsection{Upaya Meningkatkan Motivasi Kerja Karyawan PT. Orson Indonesia (bagian pabrik)}

Pimpinan atau manajer bertanggungjawab untuk mencapai tingkat keberhasilan yang tinggi dalam meningkatkan produktivitas karyawan melalui motivasi kerja dengan menerapkan disiplin kerja, sikap kerja karyawan dalam menyikapi pekerjaan yang akan dilakukan, tingkat keterampilan karyawan baik soft skill maupun hard skill, mengadakan pengawasan terhadap kinerja karyawan baik pengawasan internal maupun eksternal, menciptakan situasi yang kondusif bagi karyawan, memberikan insentif, dan memberikan kompensasi yang adil bagi seluruh karyawan.

\subsection{Jenis Motivasi yang Digunakan PT. Orson Indonesia (Bagian Pabrik) dalam Meningkatkan Produktivitas Karyawan}

1) Memberikan pendidikan dan pelatihan kepada karyawan yang mana hal ini dilakukan agar pelaksanaan pekerjaan oleh karyawan tersebut memiliki nilai dan kualitas yang lebih baik. Selain itu, juga bisa dipertanggungjawabkan, sehingga membuat para karyawan memiliki kepercayaan diri dan menumbuhkan semangat pada saat bekerja.

2) Meeting koordinasi diperlukan sebagai proses motivasi, memimpin dan mengkomunikasikan bawahan untuk mencapai tujuan perusahaan serta koordinasi pembagian kerja agar tidak tumpang tindih pekerjaan sehingga produktivitas karyawan secara efektif dan efisien

3) Briefing rutin sebagai kegiatan memotivasi karyawan untuk selalu meningkatkan kualitas produktivitas, meningkatkan kedisiplinan karyawan dalam menjalankan pekerjaan.

4) Memberikan fasilitas berupa lingkungan yang nyaman dan memiliki sifat kekeluargaan antar sesama kolega di tempat kerja. Hal ini dapat memberikan cerminan jika kondisi ini dapat menjadi sarana untuk mendukung kerja sama antara atasan dan bawahan. 
5) Memberikan insentif kepada karyawan yang dihitung melalui prestasi kerja yang didapatkan dan lama masa kerja yang telah diabdikan kepada perusahaan, yang mana insentif ini bisa berupa uang jasa.

6) Memberikan reward kepada karyawan yang mempunyai kinerja dan loyalitas tinggi kepada perusahaan.

7) Memberikan punishment kepada karyawan yang pekerjaannya kurang baik dan produktivitasnya menurun selain hukuman juga menggunakan bentuk pengarahan dan teguran pada karyawan yang melakukan pelanggaran dalam bekerja.

\subsection{Evaluasi yang Dilakukan dalam Memberikan Motivasi Kerja terhadap Karyawan PT. Orson Indonesia (bagian pabrik)}

Dalam menghadapi arus globalisasi sumber daya manusia memegang peranan penting dalam aktivitas atau kegiatan perusahaan. Berhasil atau tidaknya perusahaan dalam mencapai tujuan yang ditetapkan sangat tergantung kepada sumber daya manusia (karyawan) dalam menjalankan tugas-tugas yang diberikan kepadanya. Oleh karena itu, setiap perusahaan perlu memikirkan bagaimana cara yang dapat dilakukan untuk mengembangkan sumber daya manusianya agar dapat mendorong kemajuan baik perusahaan dan bagaimana caranya agar karyawan tersebut memiliki produktivitas yang tinggi, yang tentunya pimpinan perusahaan perlu memotivasi karyawannya. Salah satunya adalah dengan memberikan motivasi kepada karyawan. Keberadaan perusahaan sangat penting bagi perkembangan perekonomian pada suatu negara sebagai salah satu sarana bagi kehidupan masyarakatnya. Adapun di dalam aktivitas perusahaan terdapat suatu kumpulan atau dapat dikatakan kerja sama antara faktor-faktor produksi untuk menciptakan barang dan jasa yang dapat diterima dan digunakan oleh masyarakat untuk memenuhi kebutuhannya.

Dalam memberikan peningkatan biasanya menggunakan tools PDCA (Plan, Do, Check, Action) atau DMAIC (Define, Measure, Analyze, Improve, Control) untuk meningkatkan efisiensi demi mencapai keunggulan operasional bersifat 
saling melengkapi dan merupakan dasar untuk perusahaan melakukan perbaikan secara terus-menerus. Hal tersebut dilakukan pengukuran agar evaluasinya terarah dan dikontrol oleh orang yang bertanggung jawab atas jalannya pekerjaan.

Sebagai bentuk kepedulian perusahaan terhadap karyawan, perusahaan memiliki beberapa saluran komunikasi untuk mengidentifikasi dan menyerap keluhan, kritik, dan saran dari seluruh karyawan melalui departemen personalia khususnya bagian pabrik yaitu: laporan harian karyawan menuliskan permasalahan yang ditemukan selama proses produksi dan juga saran atau masukan untuk meningkatkan perusahaan terutama bagian pabrik kemudian dikumpulkan dalam laporan bulanan, dan laporan bulanan tersebut yang dijadikan bahan evaluasi manajemen dan gemba kaizen sebagai kegiatan perbaikan dan peningkatan secara terus atau berkesinambungan di tempat kerja untuk meningkatkan produktivitas karyawan.

\subsection{Hambatan atau Kendala yang Dihadapi PT. Orson Indonesia (bagian pabrik) dalam Memotivasi Kerja Karyawan}

Karyawan kurang disiplin dalam pekerjaannya dan kebiasaan karyawan itu sendiri tidak memiliki keinginan berkembang dan cenderung ada di zona nyaman. Untuk mengatasi kendala tersebut yang harus dilakukan adalah dengan mengetahui keinginan karyawan, manajer berkomunikasi langsung dengan karyawan tentang kepuasan terhadap kebijakan yang dikeluarkan perusahaan, meningkatkan kedisiplinan khususnya bagian pabrik dan melakukan pembinaan dan pelatihan untuk upgrade soft skill dan memotivasinya. 


\subsection{Pembahasan}

PT. Orson Indonesia merupakan sebuah perusahaan internasional yang berfokus pada mengembangkan usaha sabun mie, sabun toilet, sabun serbaguna dan cucian dan aneka ragam produk untuk kepentingan konsumen di seluruh dunia, serta memiliki cukup banyak karyawan terutama pada bagian pabrik, maka perusahaan menjalankan kegiatannya mengandalkan produktivitas karyawan agar tetap terus maju dan berkembang. Produktivitas karyawan menjadi fokus perhatian untuk meningkatkan produktivitas, yang berdampak pada efisiensi dan efektivitas suatu organisasi. Produktivitas karyawan dapat dipengaruhi oleh faktor keterampilan dan motivasi. Produktivitas karyawan meningkat ketika perusahaan memberdayakan dan memotivasi karyawan dengan baik.

Berdasarkan kepada data yang didapatkan, haI ini memberikan suatu gambaran jika struktur organisasi pada PT. Orson Indonesia memiliki masaIah seperti, motivasi kerja yang rendah, teamwork yang tidak efektif dan juga terdapat ketidakharmonisan pada hubungan atasan dan bawahan. DaIam mencapai keefektifan tersebut diperlukan beberapa penanganan Ianjutan, seperti: motivasi kerja rendah yang dilihat berdasarkan kepada hasil dari wawancara kepada manajer pabrik PT. Orson Indonesia, yang haI ini mendapatkan hasiI jika motivasi kerja yang rendah dapat menyebabkan perusahaan tidak bisa memanfaatkan sumber daya manusianya secara maksimal.

\subsubsection{Meningkatkan Produktivitas Kerja Karyawan Melalui Motivasi}

\subsubsection{Motivasi Kerja Karyawan}

Motivasi merupakan suatu energi yang menjadi penggerak bagi individu daIam meIaksanakan suatu haI. Studi yang dilakukan atas perilaku manusia dan motivasinya merupakan saIah satu jawaban atas apa itu manusia. Pada umumnya manusia memiliki ketergantungan akan kuatnya motif yang dimiliki, terkadang haI ini dapat meliputi keinginan atau dorongan tertentu yang terdapat di daIam diri manusia. Motivasi dapat mempengaruhi perilaku 
manusia karena sebagai pendorong keinginan dan kebutuhan seseorang sehingga dapat berenergi positif dan termotivasi untuk memenuhi dorongan diri (Bahri \& Nisa, 2017). Motivasi kerja karyawan untuk meIakukan aktivitas di tempat kerja dengan harapan dapat meIaIui semangat kerja atau dorongan yang tumbuh daIam diri seorang karyawan (Hasim, 2019).

Motivasi diarahkan kepada suatu tujuan. Yang mana motivasi merupakan suatu pendorong tambahan bagi manusia untuk melakukakn sesuatu yang mana haI ini berhubungan dengan tenaga daIam diri manusia yang membuat manusia bisa bertindak sesuai dengan keinginannya. HaI ini sama dengan bekerja, yang mana individu memiliki suatu motivasi daIam mendorong dirinya untuk bekerja. Motivasi kerja adaIah suatu kekuatan atau suatu dorongan yang diperlukan untuk bisa mencapai suatu tujuan pada pekerjaan. Adapun tujuan ini bisa terjadi dengan effort yang tinggi, yaitu sesuai dengan tenaga yang dikeIuarkan untuk menggapai tujuan itu.

HaI ini menyebabkan terdapat tiga elemen utama yang terdapat di daIam pengertian tersebut yaitu, intensitas, arah dan ketekunan. Intensitas memiliki hubungan dengan seberapa giat seseorang meIakukan usaha. Intensitas tidak bisa tercapai jika tidak ada arah yang menguntungkan. Upaya yang dilakukan secara konsisten sejaIan dengan tujuan-tujuan yang dimiliki oIeh perusahaan yang dilakukan oleh pegawai. Sedangkan ketekunan adaIah suatu ukuran atas berapa Iama orang itu bisa mempertahankan usahanya. Individu-individu yang mempunyai motivasi dapat bertahan untuk melakuakn suatu tugas pada waktu yang cukup Iama untuk bisa menggapai tujuan mereka.

Motivasi dapat dikatakan sebagai suatu energi untuk bisa mendorong keinginan di daIam diri. SeIanjutnya motivasi dan kebutuhan tidak dapat terpisahkan, kebutuhan merupakan suatu kesenjangan atau pertentangan yang diaIami oleh kenyataan dan dorongan yang ada didaIam diri. Apabila kebutuhan pegawai tidak bisa dipenuhi maka karyawan dapat menunjukkan rasa kekecewaannya. Sebaliknya, jika sudah di penuhi maka karyawan wajib 
untuk menunjukkan kebahagiaannya sebagai wujud dari kebutuhan yang teIah terpenuhi.

Pada dasarannya motivasi menyangkut dengan usaha daIam mewujudkan suatu pencapaian yang terdiri dari tiga bagian yang tidak bisa terpecahkan, yaitu: usaha, tujuan dan kebutuhan. Motivasi kerja pada karyawan dapat dilihat sebagai suatu faktor yang menyebabkan perusahaan tidak bisa memberdayakan sumber daya yang dimiliki secara maksimaI. Motivasi yang rendah ini adaIah faktor penting yang harus diperbaiki pada perusahaan. Penelitian Ianjutan akan haI ini disarankan untuk bisa memperjeIas faktor apa yang bisa menyebabkan kinerja dari karyawan menjadi Iebih rendah.

Tim kerja yang tidak efektif pada suatu perusahaan mempunyai orangorang yang bekerja secara bersamaan untuk bisa mencapai tujuannya. Sebuah tim bisa menggapai hasiI yang Iebih banyak daripada penjumIahan pada hasiI kerja secara individu. Banyak pendeketan yang dilakukan untuk bisa meningkatkan efektivitas pada perusahaan dengan cara melakukan peIatihan dan pengembangan bagi sumber daya manusia yang mereka miliki, baik dengan memberikan aktivitas akan suatu pengembangan bagi keterampilan individu, pengetahuan dan pengaIaman kerja. Akan tetapi, haI tersebut tidakIah cukup jika tidak menyentuh sisi individu yang bisa bekerja secara bersamaan.

Woodcock \& Francis menjeIaskan jika teamwork menjadi suatu haI penting daIam membangun teambuIding pada suatu perusahaan. permasaIahan yang didapatkan pada teamwork adaIah suatu masaIah pada bidang sumber daya manusia yang terdapat didaIam suatu perusahaan. terdapat beberapa hambatan utama yang bisa membuat teamwork pada suatu keIompok menjadi efektif, saIah satunya adaIah:

1) Clear Objectives and agreed goaIs mencakup cara pada suatu pengambilan keputusan, pemahaman akan suatu tujuan dari kelompok yang bisa dicapai. 
2) Openess and confrontation yang mana haI ini termasuk kedaIam ide, permasaIahan, pemikiran dan keterbukaan yang dimiliki oleh anggota di daIam kelompok.

3) Support and trust, hal ini mencakup ancaman yang akan dihadapi oleh anggota di daIam keIompok, haI ini termasuk kedaIam sikap, kepercayaan dan rasa ingin menolong yang dimiliki oleh keIompok.

4) Co-Operation and Conflict, haI ini meliputi komunikasi yang diIakukan, konflik yang dihadapi di daIam keIompok, komitmen, kerjasama, diskusi, dan juga perbedaan antar anggota

5) Sound procedures, meliputi suatu keputusan yang diambiI di daIam suatu keIompok, informasi yang didapatkan meliputi, IoyaIitas dan solusi dari masaIah yang diambil oleh keIompok.

6) Appropriate Ieadership, yang haI ini meliputi kepemimpinan yang ada didaIam keIompok dan juga tingkat kepercayaan kepada atasan.

7) Regular review, meliputi arti dari pertemuan bagi suatu kelompok, artinya beIajar dari suatu kesaIahan yang ada didaIam keIompok, rotasi dari pengerjaan tugas, pemberian umpan baIik, dan juga untuk bisa merevisi prosedur kerja.

8) IndividuaI deveIopment, hal ini meliputi suatu kesempatan untuk anggota bisa berkembang dengan arahan yang didapatkan dari atasan dan juga sebagai sarana untuk mengasah kemampuan dari anggota.

9) Sound inter-group relations, haI ini mencakup hubungan yang dimiliki antar anggota, pengaruh yang diberikan dan juga kesempatan yang dimiliki oleh anggota.

Menurut Munandar dalam (Sakiman, 2019) memberikan penjelasan tentang aspek yang dimiliki oleh motivasi kerja, diantaranya adalah sebagai berikut: 
1) Kedisiplinan yang dimiliki oleh karyawan dalam menjalankan aktivitas kerja sesuai dengan putusan dan norma yang sudah di berikan oleh perusahaan dan telah disetujui secara bersama.

2) Hasil dari produk yang dimiliki oleh karyawan dapat di lihat melalui imajinasi yang tinggi dan daya kombinasi bersifat konstruktif.

3) Kepercayaan diri dengan menghadapi dari kenyataan yang sudah terjadi dan bertanggung jawab kepada putusan yang diambil sehingga bisa menyelesaikan segala permasalahan secara baik.

4) Daya tahan kepada tekanan yang telah diberikan pada saat bekerja dan terselesaikan dengan baik.

5) Memiliki tanggung jawab dalam segala bentuk pekerjaan.

Menurut (Kadarisman, 2012) beberapa faktor yang dapat berpengaruh pada motivasi kerja karyawan yaitu meliputi:

1) Faktor internal terdiri dari; kematangan pribadi, tingkat pendidikan, keinginan dan harapan, kebutuhan hidup, kondisi kehidupan, kepuasan kerja, dan komitmen terhadap pekerjaannya.

2) Faktor eksternal terdiri dari; kondisi lingkungan kerja berupa sarana dan prasarana, kompensasi atau upah yang memadai, tingkat pengawasan yang baik, hubungan vertikal dan horizontal antar karyawan dan atasan, jaminan karier yang jelas, beban kerja yang sesuai, dan peraturan yang fleksibel.

Indikator Motivasi Kerja menurut Anwar Prabu Mangkunegara dalam (Azizah, 2019) yaitu: tanggung jawab pribadi yang tinggi pada pekerjaan baik, peluang untuk maju karena adanya keinginan mendapatkan upah yang layak sesuai dengan porsi pekerjaan, pengakuan atas kinerja yang terdorong untuk mendapat upah lebih tinggi dari biasanya, dan tantangan dalam pekerjaan.

Menurut Hasibuan dalam (Purbaningtyas \& Muchollasho, 2020) terdapat beberapa dampak dari pemberian motivasi kerja kepada karyawan diantaranya yaitu: 
1) Employee Performance menurut Sudaryo et al. dalam (Falah \& Ayuningtias, 2020) adalah hasil kerja yang dicapai individu dalam menjalankan tugas yang diberikan dan kontribusi karyawan pada perusahaan. penelitian ini telah dilakukan sebelumnya yaitu motivasi kerja mempunyai pengaruh atas performance karyawan. Berdasarkan pada penelitian yang dilakukan oleh (Falah \& Ayuningtias, 2020), (Fauziah et al., 2020) menunjukkan jika motivasi kerja mempunyai pengaruh yang positif dan signifikan atas performance karyawan, yang mana ini mempunyai arti jika semakin tinggi motivasi karyawan maka performance yang dimiliki akan semakin tinggi.

2) Work Productivity adalah kemampuan dalam menghasilkan suatu produk yang memiliki kualitas yang sesuai dengan standar yang ada dengan cara pemanfaatan sumber daya yang efisien (Laksmiari, 2019). Berdasarkan penelitian yang dilakukan oleh (Laksmiari, 2019), (Sinaga, 2020) menunjukkan bahwa motivasi kerja berpengaruh positif dan signifikan terhadap productivity kerja karyawan, yang berarti semakin tinggi motivation karyawan, maka semakin tinggi productivity kerja karyawan.

3) Job Satisfaction, motivasi tidak hanya mempunyai pengaruh terhadap kinerja dan produktivitas akan tetapi juga berpengaruh kepada job satisfaction. Menurut Rivai \& Sagala dalam (Isrial et al., 2020) Job satisfaction merupakan hasil dari evaluasi oleh seseorang yang ditunjukkan dari sikap dan perasaannya mengenai senang atau tidak senang dalam bekerja. Berdasarkan penelitian yang dilakukan oleh (Lasut et al., 2018), (Isrial et al., 2020) menunjukkan bahwa motivasi kerja berpengaruh positif dan signifikan terhadap kepuasan kerja karyawan, yang berarti semakin tinggi motivation karyawan, maka semakin tinggi Job Satisfaction karyawan.

Pimpinan selalu berusaha untuk memberikan dorongan atau motivasi pada karyawannya agar para karyawan bersemangat dalam melakukan pekerjaannya. Untuk mempermudah memotivasi bawahannya seorang pimpinan harus dapat mengetahui perilaku manusia, apa sebabnya orang mau bekerja dan kepuasan-kepuasan apa yang dinikmatinya karena bekerja. Tingkah laku seseorang dipengaruhi serta dimotivasi oleh keinginan 
kebutuhan, tujuan dan kepuasannya. Motivasi dapat timbul dari diri sendiri (internal) dan dari luar (eksternal). Motivasi juga dapat berupa motivasi materiil dan non materiil. Motivasi tersebut akan menciptakan motif dan motivasi yang mendorong orang bekerja untuk memperoleh kebutuhan dan kepuasan dari hasil kerjanya.

Agar dapat mencapai pada tingkat keberhasilan tinggi, dalam hal ini manajer melakukan upaya meningkatkan motivasi kerja karyawan dengan cara memperbaiki motivasi kerja dan menerapkan disiplin dan sikap kerja yang dimiliki oleh karyawan dalam rangka memberikan respon pada pekerjaan yang dilakukan, tingkat dari keterampilan karyawan baik berupa soft skill ataupun hard skill, melakukan pengawasan pada kinerja karyawan baik pada pengawasan internal maupun eksternal. Selain itu juga bisa dilakukan untuk menciptakan situasi yang kondusif bagi karyawan, memberikan insentif, dan kompensasi.

Permasalahan lainnya yang terjadi adalah adanya konflik antara operator produksi dengan supervisor produksi sehingga sering terjadi kesalahan dalam produksi yang berakibat work time lost dan kerugian materi. Sejauh ini penanganan konflik dilakukan dengan dilaksanakannya kegiatan outbond bulanan untuk meningkatkan komunikasi interpersonal dan keterbukaan dalam penyelesaian bersama. Upaya meningkatkan motivasi kerja karyawan sesuai dengan Anwar Prabu Mangkunegara (dalam Azizah, 2019), menyatakan beberapa teknik memotivasi kerja karyawan yaitu teknik pemenuhan kebutuhan karyawan dan teknik komunikasi persuasif. Kedua teknik tersebut dijelaskan sebagai berikut:

1) Teknik pemenuhan kebutuhan karyawan

Pemenuhan kebutuhan karyawan merupakan fundamen yang mendasari perilaku kerja. Pimpinan tidak mungkin dapat memotivasi kerja karyawan tanpa memperhatikan apa yang dibutuhkan. Anwar Prabu Mangkunegara (dalam Azizah, 2019), menyatakan beberapa hierarki kebutuhan karyawan, sebagai berikut : 
a) Kebutuhan fisiologis

Yaitu kebutuhan makan, minum, perlindungan fisik, bernapas, dan seksual. Kebutuhan ini merupakan kebutuhan yang paling mendasar. Dalam hubungan dengan kebutuhan ini pemimpin perlu memberikan gaji yang layak kepada pegawai.

b) Kebutuhan rasa aman

Yaitu kebutuhan perlindungan dari ancaman, bahaya, dan lingkungan kerja. Dalam hubungan dengan kebutuhan ini pemimpin perlu memberikan tunjangan kesehatan, asuransi kecelakaan, perumahan, dan dana pensiun.

c) Kebutuhan sosial atau rasa memiliki

Yaitu kebutuhan untuk diterima dalam kelompok unit kerja, berafiliasi, berinteraksi, serta rasa dicintai dan mencintai. Dalam hubungan dengan kebutuhan ini, pemimpin perlu menerima eksistensi atau keberadaan karyawan sebagai anggota kelompok kerja, melakukan interaksi kerja yang baik, dan hubungan kerja yang harmonis.

d) Kebutuhan harga diri.

Yaitu kebutuhan untuk dihormati, dihargai oleh orang lain. Dalam hubungan dengan kebutuhan ini, pemimpin tidak boleh sewenangwenang memperlakukan karyawan karena mereka perlu dihormati, diberi penghargaan terhadap prestasi kerjanya.

e) Kebutuhan aktualisasi diri.

Yaitu kebutuhan untuk mengembangkan diri dan potensi, mengemukakan ide-ide, memberikan penilaian, kritik, dan berprestasi. Kebutuhan inilah yang mendorong seorang seniman mengungkapkan keahliannya di atas kanvas, kebutuhan yang memotivasi seseorang untuk bekerja pada siang hari dan kemudian mengikuti kuliah sore untuk mendapatkan gelar kesarjanaan. Dalam hubungannya dengan kebutuhan ini di dalam perusahaan atau organisasi, pemimpin perlu 
memberi kesempatan kepada karyawan/bawahan agar mereka dapat mengaktualisasikan diri secara baik dan wajar di lingkungan perusahaan.

2) Teknik komunikasi persuasif

Teknik komunikasi persuasif merupakan salah satu teknik memotivasi kerja karyawan yang dilakukan dengan cara mempengaruhi karyawan secara ekstra logis. Menurut Anwar Prabu Mangkunegaran (dalam Azizah, 2019) merumuskan teknik ini : “ AIDDAS “.
$\mathrm{A}=$ Attention $\quad$ (Perhatian)
$\mathrm{I}=$ Interest $\quad($ Minat $)$
$\mathrm{D}=$ Desire $\quad$ (Hasrat)
$\mathrm{D}=$ Decision $\quad$ (Keputusan)
$\mathrm{A}=$ Action $\quad($ Aksi/Tindakan $)$
$\mathrm{S}$ = Satisfaction (Kepuasan)

Penggunaannya, pertama kali pemimpin harus memberikan perhatian kepada karyawan tentang pentingnya tujuan dari suatu pekerjaan agar timbul minat karyawan terhadap pelaksanaan kerja, jika telah timbul minatnya maka hasratnya menjadi kuat untuk mengambil keputusan dan melakukan tindakan kerja dalam mencapai tujuan yang diharapkan oleh pemimpin.

Jenis motivasi yang digunakan dalam meningkatkan produktivitas karyawan, seperti: memberikan pendidikan dan pelatihan, meeting koordinasi, briefing rutin, memberikan fasilitas yang memadai, memberikan insentif, memberikan reward, memberikan punishment hal ini sesuai dengan jenis motivasi menurut Hasibuan (dalam Purbaningtyas \& Muchollasho, 2020), antara lain :

1) Motivasi Positif (Insentif positive)

Manajer memotivasi karyawan dengan memberikan hadiah kepada mereka yang berprestasi baik. Dengan motivasi positif, semangat kerja karyawan 
akan meningkat karena umumnya manusia senang menerima yang baikbaik saja.

2) Motivasi Negatif (Insentif negative)

Manajer memotivasi karyawan dengan memberikan hukuman kepada mereka yang pekerjaannya kurang baik (prestasi rendah). Dengan motivasi negatif semangat kerja karyawan dalam jangka waktu pendek akan meningkat karena mereka takut dihukum, tetapi untuk jangka waktu panjang dapat berakibat kurang baik.

Berdasarkan dua jenis motivasi diatas, menurut Hasibuan pada (Purbaningtyas \& Muchollasho, 2020)) menyatakan bahwa motivasi di atas sering digunakan oleh suatu perusahaan. Penggunaannya harus tepat dan seimbang supaya dapat meningkatkan semangat kerja karyawan.

Sebagai bentuk kepedulian perusahaan terhadap karyawan, perusahaan memiliki beberapa saluran komunikasi untuk mengidentifikasi dan menyerap keluhan, kritik, dan saran dari seluruh karyawan melalui departemen personalia khususnya bagian pabrik yaitu: laporan harian karyawan menuliskan permasalahan yang ditemukan selama proses produksi dan juga saran atau masukan untuk meningkatkan perusahaan terutama bagian pabrik kemudian dikumpulkan dalam laporan bulanan, dan laporan bulanan tersebut yang dijadikan bahan evaluasi manajemen dan gemba kaizen sebagai kegiatan perbaikan dan peningkatan secara terus atau berkesinambungan di tempat kerja untuk meningkatkan produktivitas karyawan. Hal ini sesuai dengan prinsip motivasi kerja karyawan Menurut Anwar Prabu Mangkunegara (dalam Azizah, 2019) menyatakan bahwa terdapat beberapa prinsip dalam memotivasi kerja karyawan, yaitu sebagai berikut :

1) Prinsip partisipasi.

Dalam upaya memotivasi kerja, karyawan perlu diberikan kesempatan ikut berpartisipasi dalam menentukan tujuan yang akan dicapai oleh pemimpin.

2) Prinsip komunikasi 
Pemimpin mengkomunikasikan segala sesuatu yang berhubungan dengan usaha pencapaian tugas, dengan informasi yang jelas, karyawan akan lebih mudah dimotivasi kerjanya.

3) Prinsip mengakui andil bawahan.

Pemimpin mengakui bahwa karyawan mempunyai andil di dalam usaha pencapaian tujuan, dengan pengakuan tersebut karyawan akan lebih mudah dimotivasi kerjanya.

4) Prinsip pendelegasian wewenang.

Pemimpin yang memberikan otoritas atau wewenang kepada karyawan untuk sewaktu-waktu dapat mengambil keputusan terhadap pekerjaan yang dilakukannya, hal itu akan membuat karyawan yang bersangkutan menjadi termotivasi untuk mencapai tujuan yang diharapkan oleh pemimpin.

5) Prinsip memberi perhatian.

Pemimpin memberi perhatian terhadap apa yang diinginkan karyawan, sehingga akan mudah memotivasi karyawan bekerja apa yang diharapkan oleh pemimpin.

Karyawan kurang disiplin dalam pekerjaannya dan kebiasaan karyawan itu sendiri tidak memiliki keinginan berkembang dan cenderung ada di zona nyaman. Untuk mengatasi kendala tersebut yang harus dilakukan adalah dengan mengetahui keinginan karyawan, manajer berkomunikasi langsung dengan karyawan tentang kepuasan terhadap kebijakan yang dikeluarkan perusahaan, meningkatkan kedisiplinan khususnya bagian pabrik dan melakukan pembinaan dan pelatihan untuk upgrade soft skill dan memotivasinya. Hal ini sesuai dengan Hasibuan (dalam Purbaningtyas \& Muchollasho, 2020) menyatakan beberapa kendala, yaitu: untuk menentukan alat motivasi yang tepat itu sulit karena setiap individu karyawan tidak sama, kemampuan perusahaan terbatas dalam menyediakan fasilitas dan insentif, manajer sulit mengetahui motivasi kerja setiap individu karyawan, dan manajer sulit memberikan insentif yang adil dan layak. 


\subsubsection{Produktivitas}

Manajemen sumber daya manusia merupakan bagian dari keilmuan manajemen yang memperhatikan tentang peran dari manusia didaIam suatu perusahaan, selain itu juga memiliki tugas untuk mengatur karyawan sehingga dapat mewujudkan tujuan perusahaan secara maksimal. SaIah satu pencapaian yang ada daIam perusahaan adaIah dengan meningkatkan produktivitas dari karyawan. Perusahaan seIaIu memiliki tujuan yang mana pada masa depan dapat mengalami suatu perkembangan yang pesat pada Iingkungan usaha di perusahaan dengan bisa menciptakan produktivitas kerja di daIamnya.

Produktivitas memiliki beberapa pengertian yang dikemukakan oleh orang-orang. Umumnya produktivitas merupakan hubungan yang tercipta antara luaran dengan masukan. Atau bisa juga diartikan jika produktivitas merupakan ukuran dari efisiensi yang produktif. Terdapat beberapa faktor yang mempengaruhi produktivitas, seperti: pendidikan, keterampilan, disiplin, sikap mental, etika kerja, motivasi dan lain sebagainya. Menurut Sutrisno (dalam Nasution, 2014) untuk mengukur produktivitas kerja, diperlukan suatu indikator, yaitu sebagai berikut:

1) Kemampuan

2) Meningkatkan hasil yang dicapai

3) Semangat kerja

4) Pengembangan diri

5) Mutu

6) Efisiensi

Hal ini berarti, jika produktivitas merupakan suatu sikap yang dimiliki atas mental dan cara pandang manusia yang dilakukan untuk bisa menciptakan esok hari yang lebih baik jika dibandingkan dengan hari ini dan juga kemarin. Secara sederhana produktivitas merupakan rasio yang terdapat antara suatu luaran dan masukan yang digunakan. Produktivitas merupakan efektivitas dan 
efisiensi hasil kerja karyawan dalam melaksanakan pekerjaan atau tugasnya. Baik tidaknya hasil kerja yang dicapai sangat tergantung pada kemampuan pemimpin terhadap pemberdayaan sumber daya manusia dalam bekerja harus produktif melainkan secara kelembagaan pun perlu diperhatikan

DaIam mewujudkan tujuan dari perusahaan diperlukan faktor-faktor produksi, seperti: sumber daya aIam, sumber daya manusia, modaI dan skill. Faktor-faktor itu tidak dapat berdiri sendiri secara efektif dan efisien. Suatu bentuk dari perusahaan tidak bisa mencapai tujuan jika produktivitas yang diIakukan oIeh karyawan rendah. OIeh karenanya, produktivitas menjadi haI yang utama daIam rangka peningkatan mutu dari perusahaan. daIam aktivitasnya perusahaan diharapkan untuk dapat meningkatkan produktivitas pada suatu masa ke masa haI ini dikarenakan menyangkut pada produksi perusahaan. produktivitas yang dilakukan oleh karyawan sangatlah penting bagi tujuan perusahaan. produktivitas karyawan adalah pusat perhatian dan peran penting bagi produktivitas perusahaan.

\section{Penutup}

Berdasarkan hasil analisis data, meningkatkan produktivitas kerja karyawan menjadi prioritas perusahaan dalam membangun motivasi kerja yang kuat. Hal ini dikarenakan motivasi kerja yang kuat dapat memberikan keuntungan dan keunggulan kompetitif bagi perusahaan. Dan menjadi hal penting sebagai sarana dalam lingkungan kerja yang berkaitan dengan meningkatkan produktivitas. Jika fasilitas kerja yang diberikan oleh perusahaan memadai, maka hubungan antar karyawan akan menjadi harmonis, sehingga menyebabkan produktivitas meningkat secara optimal.

Terdapat beberapa perbedaan dan keterbatasan pada hasil penelitian empiris terdahulu, maka sangat memungkinkan untuk mengkaji lebih lanjut meningkatkan produktivitas kerja karyawan melalui motivasi PT. Orson Indonesia (bagian pabrik). Keterbatasan dari penelitian ini hanya menggunakan metode tinjauan literatur dan wawancara serta mempelajari motivasi kerja karyawan di PT. Orson Indonesia (bagian pabrik), sehingga penelitian 
selanjutnya diharapkan dapat mengetahui hubungan yang signifikan dalam meningkatkan produktivitas kerja karyawan melalui motivasi. Metode yang dapat digunakan dalam penelitian selanjutnya adalah analisis regresi linear berganda dengan menggunakan software SPSS maupun PLS (Partial Least Square).

\section{Daftar Pustaka}

Aboelmaged, M. G. (2018). Knowledge sharing through enterprise social network (ESN) systems: motivational drivers and their impact on employees' productivity. Journal of Knowledge Management (Q2), 1-22. https://doi.org/10.1108/jkm-05-2017-0188

Alamzah, E., \& Simanjutak, A. (2013). Pengelolaan Dan Pengembangan Sumber Daya Manusia Pada PT. Aneka Sejahtera Engineering. Jurnal Manajemen Bisnis Petra, 1(2), 1-12.

Amalia, S. S., Basalamah, M. R., \& Millannintyas, R. (2021). Motivasi, Disiplin, Dan Semangat Kerja Dalam Meningkatkan Produktivitas Kerja Pada Masa Pandemi Covid-19 Di KPP Pratama Sidoarjo Utara. E - Jurnal Riset Manajemen PRODI MANAJEMEN Fakultas Ekonomi Dan Bisnis Unisma, 151161.

Azizah, N. (2019). Analisis Penempatan, Motivasi Kerja, Pengembangan Karir terhadap Kepuasan Kerja. 16-49.

Bahri, S., \& Nisa, Y. C. (2017). Pengaruh Pengembangan Karir Dan Motivasi Kerja Terhadap Kepuasan Kerja Karyawan. Jurnal Ilmiah Manajemen Dan Bisnis, 18(1), 9-15. https://doi.org/10.30596/jimb.v18i1.1395

Budianto, A., Pongtuluran, Y., \& Y, S. (2017). Pengaruh Etika Kerja, Motivasi Kerja dan Kompensasi Finansial terhadap Kinerja Karyawan. Jurnal Fakultas Ekonomi Dan Bisnis Universitas Mulawarman, 14(1), 1-5. https://doi.org/10.29264/jkin.v14i1.2472

Bukit, B., Malusa, T., \& Rahmat, A. (2017). PENGEMBANGAN SUMBER DAYA MANUSIA: Teori, Dimensi Pengukuran, dan Implementasi dalam Organisasi. file://C:/Users/Smile/Downloads/manajemen sumber daya manusia ( 
PDFDrive.com ).pdf

Falah, A. M., \& Ayuningtias, H. G. (2020b). PENGARUH MOTIVASI KERJA TERHADAP KINERJAKARYAWAN PT. XYZ. Jurnal Mitra Manajemen, 4(6), 990-1001. https://doi.org/10.52160/ejmm.v4i6.417

Fauziah, H., Ayu, M., \& Syahpitra, R. T. (2020). ANALISIS PENGARUH MOTIVASI KERJA TERHADAP KINERJA KARYAWAN PADA PLAZA FOTO DI BANDAR LAMPUNG. Jurnal Ekonomi, Keuangan Dan Bisnis, 5, 53-62. https://doi.org/10.24967/ekombis.v5i1.649

Hasim, D. (2019). Pengaruh Kepemimpinan, Motivasi dan Iklim Kerja Terhadap Kinerja Pegawai Pada Dinas Kesejahteraan Sosial Kabupaten Biank Numfor. In Google Book (Vol. 2, Issue 2).

Hermawan, R., \& Rahadi, D. R. (2021). Analisa Lingkungan Kerja dan Peningkatan Kinerja Karyawan melalui Motivasi : Studi Literatur. 16(1), 118-124.

Hoornweg, N., Peters, P., \& Heijden, B. van der. (2016). Finding the Optimal Mix between Telework and Office Hours to Enhance Employee Productivity: A Study into the Relationship between Telework Intensity and Individual Productivity, with Mediation of Intrinsic Motivation and Moderation of Office Hours. In New Ways of Working Practices: Antecedents and Outcomes Advanced Series in Management (Q2) (pp. 1-28).

Husaini, A. (2017). PERANAN MANAJEMEN SUMBERDAYA MANUSIA DALAM ORGANISASI. Jurnal Warta Edisi, 11(1), 92-105.

Imas Masriah. (2020). The Influence of Motivation and Work Experience on Employee Productivity. Pinisi Discretion Review, 3(2), 331-338. https://doi.org/10.26858/pdr.v1i1.20538

Isrial, Iqbal, M., \& Chakim, M. H. R. (2020). PENGARUH GAYA KEPEMIMPINAN DAN MOTIVASI KERJA TERHADAP KEPUASAN KERJA KARYAWAN PT BANK BUKOPIN CABANG S PARMAN. JMari, 1(1), 50-59. https://doi.org/10.33050/jmari.v1i1.1088

Kadarisman, M. (2012). Manajemen Pengembangan Sumber Daya Manusia. In Rajawali Press. Jakarta (Vol. 1, Issue 1). 
Kristine, E. (2017). PENGARUH KEPUASAN KERJA DAN KOMITMEN ORGANISASI TERHADAP KINERJA MELALUI MOTIVASI KERJA PEGAWAI ALIH DAYA (OUTSOURCING) DI PT. MITRA KARYA JAYA SENTOSA. Jurnal EKSEKUTIF, 14(2), 384-401.

Laksmiari, N. P. P. (2019). PENGARUH MOTIVASI KERJA TERHADAP PRODUKTIVITAS KERJA KARYAWAN PADA PERUSAHAAN TEH BUNGA TERATAI DI DESA PATEMON KECAMATAN SERRIT. Jurnal Pendidikan Ekonomi Undiksha, 11(1), 54-63.

Lasut, J. R., Koleangan, R. A. M., \& Uhing, Y. (2018). PENGARUH PENGEMBANGAN KARIR, DISIPLIN KERJA DAN MOTIVASI TERHADAP KEPUASAN KERJA KARYAWAN PADA PT. BANK BANK SULUTGO. Jurnal EMBA, 6(4), 3993-4002.

Marlapa, E., \& Mulyana, B. (2020). The Effect of Work Discipline and Work Motivation on Employee Productivity with Competence as Interviening Variables. International Review of Management and Marketing, 10(3), 54-63. https://doi.org/10.36090/e-dj.v2i1.734

Moleong, L. J. (2017). Metode Penelitian Kualitatif (Edisi revi). PT Remaja Rosdakarya.

Moulana, F., Bambang Swasto Sunuharyo, \& Utami, H. N. (2017). PENGARUH LINGKUNGAN KERJA TERHADAP KINERJA KARYAWAN MELALUI VARIABEL MEDIATOR MOTIVASI KERJA (Studi pada Karyawan PT. Telkom Indonesia,Tbk Witel Jatim Selatan, Jalan A. Yani, Malang). Jurnal Administrasi Bisnis (JAB), 44(1), 178-185.

Mudayana, F. I., \& Suryoko, S. (2016). Pengaruh Kompetensi, Kompensasi, dan Lingkungan Kerja terhadap Kinerja Karyawan melalui Motivasi Kerja Sebagai Variabel Intervening (Studi Kasus pada Karyawan Bagian Produksi PT. Sai Apparel Industries Semarang). Jurnal Ilmu Administrasi Bisnis, 5(1), 196-205. https://doi.org/10.21009/JPEB.005.1.6

Muslikhah, E. (2011). UPAYA PENINGKATAN KINERJA KARYAWAN MELALUI MOTIVASI KERJA PADA PT. SAMPURNA KUNINGAN JUWANA-KABUPATEN PATI. 74. 
Nasution, E. (2014). MOTIVASI KERJA DALAM MENINGKATKAN PRODUKTIVITAS KERJA PEGAWAI FAKULTAS DAKWAH IAIN ARRANIRY. Jurnal Al-Bayan, 20(3), 1-14.

NST, A. E., \& Lesmana, M. T. (2018). INFLUENCE OF WORK DISCIPLINE AND SUPERVISION TO INCREASING EMPLOYEE PRODUCTIVITY IN PT. CITRA ROBIN SARANA MEDAN. Jurnal Muhammadiyah Sumatera Utara, 742-750. https://doi.org/10.31227/osf.io/bfjmp

Oktiani, N., Sabariah, E., Saridawati, \& Caroline, P. (2019). Implementasi Penerapan Motivasi Kerja dan Kinerja Karyawan Terhadap Peningkatan Produktifitas Kerja. Widya Cipta: Jurnal Sekretari Dan Manajemen, 3(2), 255262. https://doi.org/10.31294/widyacipta.v3i2.6472

Parmana, H., Yulianti, F., \& Lamsah. (2020). UPAYA MENINGKATKAN PRODUKTIVITAS KERJA KARYAWAN MELALUI MOTIVASI KERJA PADA CV TEKNIK GRUP MANDIRI ( TGM ). Jurnal Universitas Islam Kalimantan, 2.

Prihantoro, A. (2012). PENINGKATAN KINERJA SUMBER DAYA MANUSIA MELALUI MOTIVASI, DISIPLIN, LINGKUNGAN KERJA, DAN KOMITMEN. Jurnal Universitas Muhammadiyah Semarang, 8(2), 283.

Purbaningtyas, K., \& Muchollasho, W. (2020). STUDI LITERATUR MENGENAI MOTIVASI KERJA PADA KARYAWAN DALAM UPAYA MENINGKATKAN PRODUKTIVITAS KERJA KARYAWAN. 295-300.

Purnomo, H., \& Wahdiniwaty, R. (2018). The Impact of Motivation in Increasing Employee Productivity in College. Advances in Social Science, Education and Humanities Research, 225(Icobest), 39-41. https://doi.org/10.2991/icobest-18.2018.10

Rahmawati, D. (2013). PENGARUH MOTIVASI TERHADAP PRODUKTIVITAS KERJA KARYAWAN PR FAJAR BERLIAN TULUNGAGUNG. Jurnal Universitas Tulungagung Bonorowo, 1(1), 1-16.

Safitri, E. (2017). PENGARUH MOTIVASI DAN DISIPLIN KERJA TERHADAP KINERJA KARYAWAN KOPERASI TELKOM KOTA JAMBI. Jurnal Fakultas Keguruan Dan Ilmu Pendidikan Universitas Jambi. 
Sakiman. (2019). Peran motivasi kerja dan kepuasan kerja terhadap kinerja guru taman kanak-kanak non-PNS Kabupaten Kulon Progo. Jurnal Psikologi Terapan Dan Pendidikan, 1(1), 30. https://doi.org/10.26555/jptp.v1i1.15130

Sinaga, S. (2020). PENGARUH MOTIVASI DAN PENGALAMAN KERJA TERHADAP PRODUKTIVITAS KERJA KARYAWAN PADA PT. TRIKARYA CEMERLANG MEDAN. Jurnal Ilmiah METADATA, 2, 159-169. https://doi.org/10.47652/metadata.v2i2.28

Suryantika, I. M. K., \& Wibawa, I. M. A. (2020). KOMPENSASI, DISIPLIN KERJA, DAN MOTIVASI KERJA BERPENGARUH TERHADAP PRODUKTIVITAS KARYAWAN JIMBARAN BAY SEAFOOD CAFÉ KEDONGANAN. E-Jurnal Manajemen Universitas Udayana, 9(3), 100810027. https://doi.org/10.24843/EJMUNUD.2020.v09.i03.p10

Sutrisno, \& Sunarsi, D. (2019). The Effect of Work Motivation and Discipline on Employee Productivity at PT. Anugerah Agung in Jakarta. Jurnal Administrare: Jurnal Pemikiran Ilmiah Dan Pendidikan Administrasi Perkantoran, 6(2), 187-196. https://doi.org/10.26858/ja.v6i2.13438

Wicaksono, D. A. (2011). PENINGKATAN PRODUKTIVITAS KERJA KARYAWAN MELALUI KEPEMIMPINAN, DISIPLIN KERJA, MOTIVASI, DAN KOMPENSASI PADA PT. DANATRANS SERVICE LOGISTICS SEMARANG. 67(2), 174-185. 